Fernanda F. Fernandez Jankov*

doi: 10.5937/spz64-29795

\title{
REVISITING THE DOCTRINE OF STATE JURISDICTION IN INTERNATIONAL CRIMINAL LAW
}

\begin{abstract}
This article aims at analysing the main mechanisms available, for setting limits to the exercise of State Criminal Extraterritorial Jurisdiction, mainly as it applies to International Crimes in the absence of direct links between the conduct of the accused person and the State.

Initially, jurisdiction is examined as a legal concept, for later to be approached within the delimitation of the State power to exercise its jurisdictional competence horizontally (among States), as it is not in the scope of this article the vertical exercise of State Jurisdiction (State \& International Courts).

Keywords: international criminal law, jurisdiction.

\section{Introduction}

In order to revisit the doctrine of state jurisdiction in international criminal law, that article is structured as follows:

In Part 1 - International jurisdiction as a legal concept, the concept of jurisdiction is focused from the perspective of domestic and international law, as arguably the concept has in the doctrine a two-folded definition that requires a clear understanding of the parameters that apply to its international dimension.

In Part 2 - Types of jurisdiction, jurisdiction is analysed based on the concept of international jurisdiction, demonstrating the mechanisms through which the state exercises its jurisdictional power, as part of its sovereignty.

In Part 3 - Jurisdictional grounds are addressed as a method for setting limits to the state exercise of criminal extraterritorial jurisdiction. In the absence of a direct link between the conduct of the accused person and the state, international criminalisation comes as the one criterion currently available that constitutes arguably, a legal ground for the exercise of state criminal extraterritorial jurisdiction.
\end{abstract} *PhD, Legal Faculty, University of Sao Paulo, Brasil; Fernandez \& Jankov Legal Intelligence, Brasil, Portugal,
Serbia, e-mail: fernandez.jankov@fernandezjankov.eu 


\section{International jurisdiction as a legal concept}

Initially, the term 'jurisdiction' is defined from the perspective of the present doctrine, as a form of power (Capps, Evans \& Konstadinides, 2003) that expresses itself as competence. As a consequence, state jurisdiction will be defined as the judicial, legislative and executive competence of a certain state based on international law to govern persons and property (Akehurst, 1972-1973, pp. 145-259). According to Lord MacMillan observed in Compania Naviera Vascongado v SS Cristina (Triggs, 2006, p. 344):

'It is an essential attribute of the sovereignty of this realm, as of all sovereign independent States, that it should possess jurisdiction over all persons and things within its territorial limits.'

Brownlie, Professor at Oxford University, approaches the concept of 'jurisdiction' as interconnected with the concept of 'sovereignty', as a complement of state rights (Verzijl, 1968, pp. 256-292, according to: Brownlie, 1990). Based on his understanding, 'sovereignty' is the legal personality that comprehends statehood, whereas 'jurisdiction' addresses certain aspects of the content, rights, liberties and powers (Brownlie, 1990).

Therefore, there would be a direct relation between 'sovereignty' and 'jurisdiction', with the former depending upon the latter.

Cassese (2001), Professor at Florence University, understands that 'jurisdiction' constitutes one of the powers and rights that result from 'sovereignty'.

Once again, it is possible to notice how broadly the concept is used, which leads to the conclusion that there is a distinction between the notion of jurisdiction applied by the municipal law and that applied to international public law.

According to Mann (1990 [1984]), in approaching the issue of 'jurisdiction' the international public law experts have in mind the right of a specific state, based on international law to regulate the conducts not exclusively domestic.

Therefore, the legal concept of 'international jurisdiction' applies to the international right of the state to create rules, apply them to a certain case and enforce them. Jurisdiction relates to what has been described as a pillar of public international law, as its function is to regulate and limit state competence (Mann, 1990 [1984], p. 8).

\section{Types of jurisdiction}

'Jurisdiction' in international law, describes, in general, the state legal power to define and enforce rights and duties. Based on this broad notion of the concept, the state exercises its jurisdiction by setting norms (prescriptive jurisdiction), by setting the legal procedure aiming the identifying the violation of norms and the consequences for such violation (adjudicative jurisdiction) and the enforcement through the loss of liberty or property as means of sanction (executive/enforcement jurisdiction). 
In criminal law, prescriptive and adjudicative jurisdictions are two sides of the same coin, as states do not apply foreign criminal law. If a certain court has jurisdiction, it will apply its material law, therefore if a court has jurisdiction, lex fori comes into play (Akehurst, 1972-1973, p. 179).

As the paper focuses on state criminal jurisdiction, the analysis is centred on prescriptive and executive/enforcement jurisdiction.

\subsection{Prescriptive jurisdiction}

'Prescriptive or legislative jurisdiction' must be distinguished from sovereignty. Being so, the doctrine of prescriptive jurisdiction should apply to the issue of whether and in what circumstances a state can exercise its right to legislate (Mann, 1990 [1984], p. 9).

Whatever is the international aspect in play, in principle 'jurisdiction' belongs to a state, and is limited by international law norms (Advisory Opinion No. 4, pp. 23-24, in: Mann, 1973 [1964]), following certain criteria. Therefore, 'jurisdiction' has the role of allocating legislative powers to States and in doing so, the relationship with conflict of laws, becomes also relevant (Mann, 1984, p. 9).

As Mann (1973 [1964]) elaborates on this criteria, the concept of conflict of laws as a central part of international private law is revisited, as this is a field of law that essential works on the issue of 'conflict of laws' and is then, applied as a relevant tool for international public law (Mann, 1990 [1984], p. 10).

The question of 'what are the limits of the right of a state to impose its laws', 'which are the persons and events subject to it', are issues related to the 'prescriptive jurisdiction' (Lowe, 2003, p. 333). Without it, everything is rancour and chaos (Higgins, 1994, p. 56).

\subsection{Executive/enforcement jurisdiction}

The fact that a state has 'prescriptive jurisdiction' concerning certain crime committed abroad, does not authorise this state to take measures against the accused in a foreign state, neither to arrest him and bring him for a trial in its territory.

'Prescriptive jurisdiction' of a certain state ensures 'enforcement jurisdiction' to be exercised in its territory. However, 'enforcement jurisdiction' concerns the situation in which a state exercises its 'prescriptive jurisdiction' in a foreign state, and therefore the issue of how to regulate this type of exercise emerges. It relates to the state authority under international law to apply its criminal norms using the force, if necessary, through police and its courts (O'Keefe, 2004, p. 736).

Therefore, 'enforcement jurisdiction' is manifested as a criterion to determine the circumstances under which a State can exercise its sovereignty as O'Keefe (2004) observes:

(...) Enforcement jurisdiction concerns not the law prescribed by a State to regulate, inter alia, acts outside its own territory, but the lawfulness of the State's own acts to give effect to such regulation. Enforcement jurisdiction, therefore, 
is concerned with the question whether and if so in what circumstances a State may act in the sense of exercising sovereign authority, performing acts jure imperii. The case of a State entering into a commercial transaction or being a party to commercial arbitration, acting jure gestionis, being involved in 'actus qui a rege sed ut a quovis alio fiant', is entirely outside the scope of the present discussion (Mann, 1990 [1984], p. 18).

\section{Jurisdictional grounds: the role of international criminalisation}

The classical grounds for jurisdiction have been territory and nationality. However, states have cautiously also relied on other grounds, as the principle of national protection, passive personality - where the victim of the wrongful act is a national of the state (Triggs, 2006, p. 344). Lately, the concept of international criminalisation has come into play, mainly in a two-folded jurisdictional ground: international crimes and the principle of universality.

Therefore, this paper suggests that there must be a clear distinction between the jurisdictional grounds, based on the direct link with the state that claims jurisdiction over a certain 'conduct/act' qualified as a 'crime' in its domestic criminal law, and 'international criminalisation', which does not require any direct link, simply the fact that this 'conduct/ act' is per se an 'international crime'.

This paper focuses on the mechanism of international criminalisation, as presupposes the concept of 'international crime' and generally in other for the state to incorporate it in its criminal law, the principle of jurisdiction as a 'jurisdictional ground' is used.

Within the system of national repression, international criminality may have a customary or conventional origin, in this case direct (criminality directly instituted by an international convention) or indirect (criminality instituted by domestic law, based on an international obligation) (Yokaris, 2000, pp. 897-904). However, in general, for 'civil law' countries, customary origin requires the existence of a law, which allows the 'entry' of this legal rule into the internal system. It is in reality an issue widely debated in international law, concerning monism and dualism. ${ }^{1}$

In practice, there is also the incrimination derived from an institutional act of an international organization, as is the case with international criminal courts, and it can also occur through international custom, as is the case with piracy.

For the hypothesis of direct conventional criminality, the constitutive elements are defined in the convention; therefore, it is not for the state to take legislative measures in material terms, it is enough to establish only the applicable procedural rules, especially regarding the competence of its internal organs.

\footnotetext{
${ }^{1}[\mathrm{t}]$ he dualist view, is that international law and national legal systems are two separate legal orders, existing independently of one another [...]. A consequence of these differences is that national courts are not bound to apply international law unless and until that law has been made part of the law of the land by domestic usage or legislation (Triggs, 2006. p. 105). The monist view is proposed by Kelsen (2005), according to which international and municipal law are considered not as two separate systems, but interconnected in such a way that international law is supreme.
} 
According to Yokaris (2000, p. 897), it is an obligation to achieve certain results: states agree to punish and commit to editing the internal rules necessary for this type of repression.

As an example, we can cite article 4 of the United Nations Convention against Torture and Other Cruel, Inhuman or Degrading Treatment or Punishment of 1984, according to which:

1. Each State Party shall ensure that all acts of torture are offences under its criminal law. The same shall apply to an attempt to commit torture and to an act by any person which constitutes complicity or participation in torture.

2. Each State Party shall make these offences punishable by appropriate penalties which take into account their grave nature.

Following the same reasoning (Yokaris, 2000, p. 897), this would be based on an obligation of means: states undertake to propose to their legislators the measures necessary to implement the obligation to incriminate and prosecute imposed by the Convention or by an institutional act of an international organization.

\subsection{International crimes}

The term tends to be used with some frequency; however, it must be clarified if it is being used generically, in relation to common crimes (as opposed to international ones) with international ramifications, opposing to crimes of merely local impact, or whether it should be applied to crimes created by international law.

For the purposes of this work, we opted for the second approach, according to which these crimes are defined based on their historical evolution in the context of the processes of elaboration of international criminal law.

In general, they are considered an application of the principle of universality, but this understanding is not entirely correct, as clarified by Brownlie (1990). The violated norm is that of international law, which considers the act to be a crime, not a norm of national law founded on the freedom conferred on states by international law, in which case the act is not considered a crime under international law.

\subsection{Principle of universality}

A considerable number of states have adopted, generally with limitations, a principle allowing the exercise of jurisdiction in relation to the acts of non-nationals, in which circumstances, including the nature of the crime, justify their repression as a matter of international public policy.

According to Lowe (2003), the principle applies to crimes that, due to their gravity, all states have a legitimate interest in their repression. In his opinion, this would be the traditional justification for this principle. 
Employing this ground of jurisdiction, national courts have prosecuted and tried violations of the Geneva Conventions, including Article 3 and the Protocol II, as demonstrated by the Belgian legislation of July 16, 1993, Crimes de droit International (Meron, 1998, p. 30; Fernandez-Jankov, 2020, pp. 95-109).

From the perspective of the criminal jurisdiction of states, universal jurisdiction, or better known as the principle of universal jurisdiction, is configured as the possibility for the state to exercise prescriptive jurisdiction in the case of non-existence of any other recognised jurisdictional link, on the lapse of time in which the crimes in question takes place (O’Keefe, 2004, pp. 735-760; Vešović, 2020, pp. 7-30).

Therefore, according to the principle of universality, a state affirms its competence without any criteria of direct connection with the violation, even without the need for the perpetrator to be present in its territory (see Arrest Warrant of 11 April 2000).

O'Keefe (2004, p. 745) also points out that the term 'universal jurisdiction' is the abbreviation for 'universal jurisdiction to prescribe (legislate)' or 'universal prescriptive jurisdiction' and the reference point for applying this to a given case is the 'moment when the putative conduct was committed'.

Some authors distinguish this principle, applicable to certain crimes, from the principle of conditioned universality (principe de l'universalité conditionnelle), which requires the satisfaction of certain conditions, including the presence of the alleged perpetrator in the State's territory (judex loci deprehensionis), so that jurisdiction can be exercised in response to his non-extradition to another country.

In this hypothesis, subsidiary competence (subsidiaire; subsidiary universality principle) is present. Some still speak about almost universal competence. Others talk about a quasi-universal (quasi universelle) or alternative, given that the state that detains the accused has a choice between judging - through due process of law or extraditing (aut dedere aut judicare ou aut dedere aut prosequi).

According to this reasoning, the principle of absolute universality (principe de l'université absolute), applicable to all states, must be distinguished from the principle of conditional universality (principe de la compétence relative, délégue), applicable between states parties to an international agreement or a treaty.

However, for the purposes of this work, it is argued that in setting the limits of the right of all states to repress these conducts, there is a duty based on a minimum standard established by states, based on the exercise of this right, which creates a constant obligation in an international agreement 'aut dedere aut judicare' type.

\section{Conclusion}

[1] The legal concept of international jurisdiction is interconnected with the concept of sovereignty and has a two-folded mechanism of exercise. One is centred on its domestic application, where it is manifested as a form of legal power that is arguably intrinsically related to sovereignty, which constitutes the power of the state to wield authority over a person living on its territory and the power to freely use and dispose of its own territory 
(Cassese, 2001, p. 89). The other is centred on its international application, which requires the coordination in a vertical level of the extraterritorial exercise of jurisdiction as a power previously defined on its domestic application. In this sense, it relates to what has been portrayed as one of the essential roles of public international law, the role of regulating and delimiting state competence.

It is relevant to point out at this level how that concept of jurisdiction shifts to competence once the interrelation of all 'states' jurisdictions' in horizontal level needs to be coordinated by international law. For the purpose of the current study this second approach is addressed, as the focus is to analyse the limits to the exercise of State criminal extraterritorial jurisdiction.

[2] The exercise of international jurisdiction is three dimensional based on the notion that states exercise their jurisdiction by setting norms (prescriptive jurisdiction), by setting the legal procedure through which such norms apply to a concrete case (adjudicative jurisdiction) and the consequent enforcement of the 'concrete norm applied to the case' (Dworkin, 1986) (enforcement/executive jurisdiction).

As the state judiciary does not apply, as a general rule, the material law of another state, in criminal law prescriptive and adjudicative jurisdiction end up as the same pattern of jurisdiction exercised. Based on this understanding, it is possible to conclude that the exercise of extraterritorial State jurisdiction refers to the exercise of 'prescriptive jurisdiction'.

Moreover, as it applies to criminal law, 'prescriptive jurisdiction' 'refers to a State's authority under international law to assert the applicability of its criminal law to a given conduct' (O'Keefe, 2004, p. 736).

[3] Jurisdictional grounds as a mechanism that arguably is central to the delimitation of the state's international jurisdiction should be split into two main aspects: the presence of a direct link between the conduct of the accused person and the non-existence of such link.

The jurisdictional grounds based on the presence of a direct link have been extensively studied by the doctrine, thought the works previously mentioned in this article, among other scholars. Arguably their application does not impose a challenge to the States having the Territorial Principle as the essential ground in the legislation and in some cases the nationality of the victim and rarely the nationality of the accused person.

[4] The exercise of Criminal Extraterritorial Jurisdiction in the event of the nonexistence of a direct link can only be justified, arguably, in the presence of 'International Criminalisation', which implies the presence of 'International Crimes' and its repression thought the Principle of Universality. This Principle was previously in this article defined in terms of the States exercise of 'prescriptive jurisdiction', which is arguably limited by the concept of International Crimes and its repression, that even though, having its origin on the right of the States to exercise its Extraterritorial Criminal Jurisdiction, sets a minimum standard as a constant obligation in an international agreement of 'aut dedere aut judicare' type. 


\section{References}

Akehurst, M. 1972-1973. Jurisdiction in International Law. British Yearbook of International Law, 46, pp. 145- 259.

Brownlie, I. 1990. Principles of Public International Law, $5^{\text {th }}$ ed. New York: Oxford University Press.

Capps, P., Evans, M. \& Konstadinides, S. (eds). 2003. Asserting Jurisdiction. International and European Legal Perspectives. Hart Publishing.

Cassese, A. 2001. International Law. New York: Oxford University Press.

Dworking, R. 1986. Law's Empire. Massachusetts. USA: The Belknap Press of Harvard University Press. Cambridge.

Fernandez-Jankov F. F. 2020. Pojam međunarodnog krivičnog dela i njegova evolucija. Strani pravni život, 64(2), pp. 95-109.

Higgins, R. 1994. Problems and process: international law and how we use it. United States: Oxford University Press.

Kelsen, H. 2005. Pure Theory of Law. Translated from the Second (Revised and Enlarged) German Edition by Max Knight. Clark, New Jersey: The Lawbook Exchange Ltd.

Lowe, V. 2003. Jurisdiction. In: Evans, M. (coord.), International Law, $1^{\text {st }}$ ed. New York: Oxford University Press, pp. 327-385.

Mann, F. A. [1984]. The Doctrine of International Jurisdiction Revisited After 20 Years (Volume 186). In: Collected Courses of the Hague Academy of International Law. Reproduced in: Mann, F. A. 1990. Further Studies in International Law. Oxford: Claredon Press.

Mann, F. A. [1964]. The Doctrine of Jurisdiction in International Law (Volume 111). In: Collected Courses of the Hague Academy of International Law. Reproduced in: Mann, F. A. 1973. Studies in International Law. Oxford: Claredon Press.

Meron, T. 1998. Is International Law Moving towards Criminalization?. European Journal of International Law, 9(1), pp.18-31.

O'Keefe, R. 2004. Universal Jurisdiction. Journal of International Criminal Justice, 2, pp. 735-760.

Verzijl, J. 1968. International Law in Historical Perspective. Leiden: Brill|Nijhoff. In: Brownlie, I. 1990. Principles of Public International Law, $5^{\text {th }}$ ed, New York: Oxford University Press.

Vešović, M. D. 2020. Osnovne karakteristike univerzalne jurisdikcije u savremenom krivičnom pravu. Strani pravni život, 64(3), pp. 7-30.

Triggs, G. 2006. International Law: Contemporary Principles and Practices. Australia: LexisNexis. Butterworths.

Yokaris, A. 2000. Les Critères de Compétence des Juridictions Nationales. Chapitre 73. In: Ascensio, H. Decaux, E. \& Pellet, A. (Coord.), Droit International Pénal. Paris: CEDIN Paris X, Éditions A. Pedone, pp. 897-904. 


\title{
Legal sources and case law
}

Advisory Opinion No. 4, Nationality Decrees Issued in Tunis and Morocco, 4, Permanent Court of International Justice, 7 February 1923.

Arrest Warrant of 11 April 2000, Congo, The Democratic Republic of the v Belgium, Judgment, Merits, Preliminary Objections, ICJ GL No 121, [2002] ICJ Rep 3.

Compania Naviera Vascongado v SS Cristina [1938] AC 485.

United Nations Convention against Torture and Other Cruel, Inhuman or Degrading Treatment or Punishment of 1984, Resolution 34/180 General Assembly of the United Nations, 18. 12. 1979.

\section{Dr Fernanda F. Fernandez Jankov}

Pravni fakultet, Univerzitet u Sao Paulu, Brazil

Fernandez \& Jankov Legal Intelligence, Brazil, Portugal, Serbia

e-mail: fernandez.jankov@fernandezjankov.eu

\section{PREISPITIVANJE DOKTRINE NADLEŽNOSTI DRŽAVE U MEĐUNARODNOM KRIVIČNOM PRAVU}

\author{
Sažetak
}

Ovaj članak ima za cilj analizu glavnih raspoloživih mehanizama za postavljanje ograničenja u vršenju državne krivične eksteritorijalne nadležnosti, uglavnom pošto se odnosi na međunarodne zločine u odsustvu direktnih veza između ponašanja optuženog i države.

Prvobitno se nadležnost ispituje kao pravni koncept, da bi mu se kasnije pristupilo u okviru razgraničenja državne vlasti da svoju jurisdikcionu nadležnost vrši horizontalno (među državama), jer u delokrugu ovog člana nije vertikalno vršenje državne nadležnosti Državni i međunarodni sudovi).

Ključne reči: međunarodno krivično pravo, nadležnost.

Article history:

Received: 9 December 2020

Revised: 31 December 2020 Accepted: 20 January 2021 